\title{
ASSESSMENT OF LANDSCAPE CHANGE OF LESSER HIMALAYAN ROAD CORRIDOR OF UTTARAKHAND, INDIA
}

\author{
UJJWAL SUR ${ }^{1} \&$ PRAFULL SINGH ${ }^{1,2^{*}}$ \\ ${ }^{1}$ Amity Institute of Geo-Informatics and Remote Sensing, Amity University-Sector 125, \\ Noida, U.P., India \\ ${ }^{1,2}$ Department of Geology, Central University of South Bihar, Gaya, 824236, India \\ *Corresponding authore-mail: pks.jiwaji@gmail.com
}

Received: $2^{\text {nd }}$ August 2020, Accepted: $30^{\text {th }}$ August 2020

\begin{abstract}
The spatio-temporal monitoring and understanding of the pattern of land-use and land-cover (LULC) change in the Himalayas are essential for sustainable development, especially from environmental planning and management perspective. The increasing anthropogenic activities and climate change in the Siwalik and Lesser Himalayas have substantially experienced rapid change in the natural landscape; however, detailed investigation and documentation of such observed changes are limited. This study aims to assess the LULC changes along the Kalsi-Chakrata road corridor located in the Lesser Himalayan region of Uttarakhand state of India using remote sensing and geographic information system (GIS) for the periods 2000-2010 and 2010-2019. The LULC maps were generated from multi-temporal satellite images of the Landsat -7 Enhanced Thematic Mapper Plus $\left(\mathrm{ETM}^{+}\right)$series for 2000 and 2010, and the Linear Imaging Self-Scanning System IV (LISS IV) images from Resourcesat-1 for 2019. The extent of spatial landscape changes occurred in different LULC classes was performed through the cross-tabulation change matrix in the GIS module up to the individual village level. The results indicate that the forest cover of the area was intensively converted to open areas, sparse vegetation, and different land-use categories. These included agricultural land, built-up areas, and decreased from $47.27 \%$ in 2000 to $36.66 \%$ in 2019. During the same period, the open areas and agricultural areas were increased by $15.86 \%$ and $4.49 \%$, respectively. Moreover, the built-up areas (both urban and rural settlements) were progressively increased from $0.33 \%$ in 2000 to $0.56 \%$ in 2019 . The conversion of forests and sparsely vegetative areas to agricultural land and rural settlements is closely associated with the increasing anthropogenic activities due to population growth, tourism, movement of heavy vehicles for mining and other economic activities. The changes in land-cover to land use classes are more prominent in Samalta Dadauli, Nithala, Bhugtari, and Udapalta villages located between Kalsi and Sahiya town. The reported maximum transition of forest areas into the open area, agricultural land, and sparse vegetation indicates the possible scarcity of water, which could link with the incidence of climatic or seasonal variation in the Lesser Himalayan terrain to the hydro-geomorphic and anthropogenic processes. The trend in LULC change at the village level gave the insight to help to prioritize future mitigation planning and sustainable development that are exceedingly convenient for the planners, policymakers, and local
\end{abstract}


Sur U., Singh P.: Assessment of landscape change of Lesser Himalayan road corridor of Uttarakhand, India

authorities for comprehensive forest management, biodiversity strategies, and necessary conservation

Keywords: Land-use and land-cover (LULC); remote sensing; GIS; change detection; Lesser Himalayas; village land-cover conversion

\section{INTRODUCTION}

The mapping of land-use/land-cover (LULC) and detection of changes over time has become an integral and essential component in emerging the plans and policies for sustainable development of an area. The development of landscape is a long term process that gets affected by several factors, both natural and anthropogenic, at a local scale to regional scale (Petit et al., 2001). The unceasing growth of population and their increasing socio-economic needs creates enormous pressure on the land resources, often resulting in uninhibited and unplanned development transforming the natural landscape of an area (Singh et al., 2016). Considerable attention has been given by the environmentalists and ecologists to study the dynamics of LULC change and the immediate impacts of such changes on the local climate, environmental impacts in the form of biodiversity loss, groundwater depletion, increasing built-up areas, and other associated issues like flooding, landslides, salinity, land degradation, etc. (Turner et al., 2001; Mas et al. 2004; Diwedi et al., 2005; Chaudhuri et al., 2018; Prancevic et al., 2020). Hence, uncovering the LULC change for detection of the landscape transformation plays a significant role in assessing environmental impact and global climate change to address the global environmental issue (Turner, 2004). Furthermore, such studies are significant for the local agencies in providing key ingredients to landscape sustainability focusing on the conservation and restoration aspects (Riechers et al., 2020).

The natural factors that influence the primary and secondary natural landscape are mainly governed by the geomorphological processes of weathering and erosion (Geertsema et al., 2009). Conversely, among the anthropogenic factors, the construction of roads, extraction of minerals, growing habitation, and deforestation are some prevailing activities that often found to alter the landscape within a short period. Particularly in the developing countries, the rapid changes in LULC have been observed in depleting or deteriorating the reserve of vital natural resources such as water, soil, vegetation cover resulting in environmental issues (Brandt \& Townsend, 2006; Spruce et al., 2020; Arficho \& Thiel, 2020). This increasing transformation is alarming and further under the influence of climate change, and such changes can significantly impact the environment at the local, regional, and global scale. Furthermore, it is apparent that the land-cover change due to anthropogenic activities influences the global carbon cycle and contributes to worldwide warming across the continents at various levels (Alves \& Skole, 1996; Shrestha et al., 2012; Bartar et al., 2017; $\mathrm{Yu}$ et. al., 2020). Hence, the periodic LULC evaluation is an essential step for monitoring environmental transformations and managing the natural resources sensibly (Lambin et al., 2001; Geertsema et al., 2009; Singh, 2012; Twisa et al., 2019).

Many of the mountains in the world, including the Himalayas, shows highly fragile ecosystems that are considerably affected by the processes of land-use changes and impacts of the climate change (Ives \& Messerli, 1990; Macchi, 2010; Bartar et al., 2017). Several past studies revealed the ongoing problem of environmental degradation in different parts of the Himalayas and recognized deforestation and biodiversity threat due to rapid and extensive changes in the land-cover attributable to both anthropogenic and natural drivers (Singh \& Singh, 1991; Meyer \& Turner, 1992; Tiwari, 2008). The Lesser Himalayas of Uttarakhand 
experiences a higher degree of human interference, mostly in construction activities, cultivation, deforestation, construction of roads cutting the slopes, more vehicular movements, mining, and other economic activities which have caused substantial environmental issues and impacts (Sharma \& Roy, 2007; Pachauri, 2010; Joshi et al., 2012; Sur \& Singh, 2019). According to the Ministry of Environment and Forests (MoEF), Govt. of India, since 1980, 44,868 hectares of forest land in Uttarakhand have been transformed into non-forest use primarily due to construction of roads, hydro-projects and transmission lines. To better understand the changing behavior of a landscape, therefore, it is imperative to study the changing nature of land-use and land-cover (LULC) in an area. Because the correlation between the changes in LULC over the years may help understand the link with the physical and hydro-meteorological processes, infrastructure development, and economic activities at a local level. Such an approach may help uncover future trends in parts of the Lesser Himalayas, where in-depth studies applying the contemporary techniques are not carried out. It is evident from the literature survey that human activities often lead to reforms and alterations in the natural landscape in the hilly terrain of the Lesser Himalayas of Western Uttarakhand where such transformations are rapid, and it has a profound impact on the livelihood of the people and their socio-economic conditions (Sur \& Singh, 2019). The Kalsi-Chakrata area, a road corridor in the Lesser Himalayas of Uttarakhand, India, is one area where no in-depth studies were carried out to identify the spatial occurrences of natural resources and the spatial and temporal monitoring of LULC change applying the contemporary and reliable techniques.

Satellite remote sensing techniques integrated with the geographic information system (GIS) have long been considered an essential and prevailing tool for creating a spatial inventory of the natural resources in an area and monitoring the spatial and temporal changes of LULC at different spatial scales. It plays a significant role in developing a correlation between various LULC classes and detection of their transformation patterns over a period which is an important aspect to manage the environmental issues (Carlson et al., 1999; Guerschman et al., 2003; Chaudhuri et al., 2018; Twisa et al., 2019; Verma et al., 2019). The LULC change study helps to identify and analyze the changing pattern and their transformation processes and provides a clear picture to envisage the impact land-use practices on LULC conversion in that area. Such studies also aid to understand the drivers of LULC changes and examine the factors helping mitigate LULC transformation at a local scale (Ridding et al., 2020; Arficho \& Thiel, 2020).

Several studies have proven the effectiveness of combined use of RS and GIS technique as a cost-effective and robust method for LULC mapping applying numerous techniques namely; (1) image rationing; (2) image differencing; (3) knowledge-based image segmentation; (4) principal component analysis (PCA); (5) neural networks; (6) object-oriented classification; (7) change vector analysis (CVA); (8) artificial intelligence (AI), etc. It may be noted that not any single method can answer the LULC classification problem across the globe universally owing to the degree of complexity exists in the natural environment (Daniel et al., 2002; Coppin et al., 2004; Chaudhuri et al., 2018; Spruce et al., 2020). The choice of techniques depends on the objective of the study, the level of LULC classification desired, the topography of the area, the satellite images used, etc. Often, a hybrid approach has been noted more suitable to address the complexities of the system in an area well supported by intensive field investigation. Following this approach, the key objectives of the present study are to (1) analyze the spatio-temporal trends in LULC change from 2000 to 2019; (2) develop a correlation between LULC changes and identify the village hotspots for detailed investigation at a local scale for future mitigation planning and 
Sur U., Singh P.: Assessment of landscape change of Lesser Himalayan road corridor of Uttarakhand, India

sustainable development. The outcome of the study is expected to be exceedingly convenient to planners, policymakers, and local authorities.

\section{STUDY AREA}

The study area, i.e., the Chakrata-Kalsi road corridor, is located in the lesser Himalayan ranges in India's Uttarakhand state. This $42 \mathrm{~km}$ long road corridor, connects the towns of Kalsi and Chakrata and passes through 34 Census villages and one urban area (Chakrata Cantonment Board) covering an area of approx. 83 sq. km. As per the Census of India (2011), more than 16,600 people are residing in 2,700 households in the study area.

The Tiuni-Deoban forest range bounds the study area in the north, tons river flowing along Uttarakhand-Himachal Pradesh border in the west, Mussourie-Nagthat hills in the east and Yamuna River in the south. Amlawa, a tributary of Yamuna River, is the main river in the study area that originates in the Chakrata Hills (Deoban Peak). According to the Bureau of Indian Standards (BIS), the entire study area falls in seismic zone V, and the Main Boundary Fault (MBT) passes through the road corridor.

Fig. 1: Location map of the study area

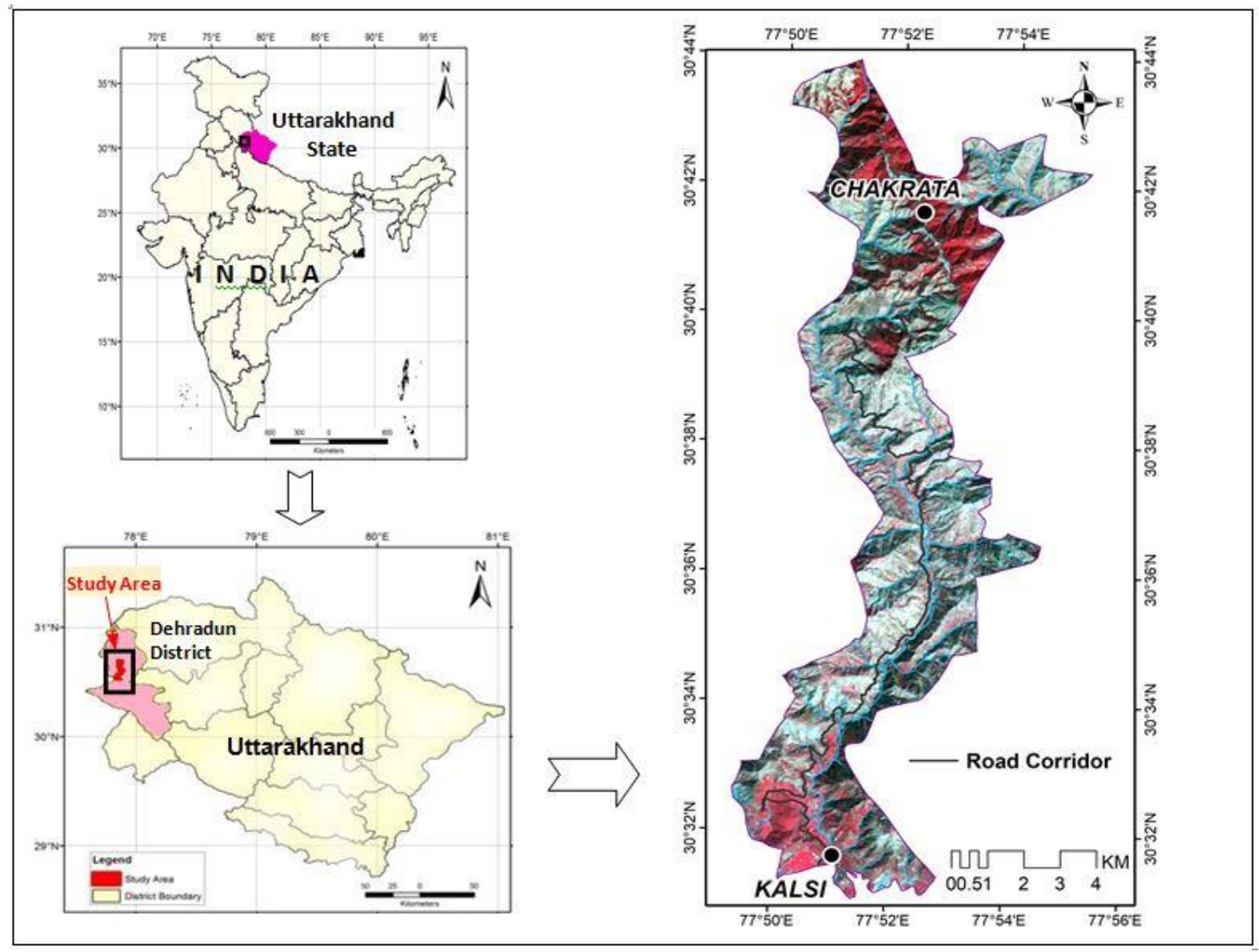


The road corridor is situated in the Siwalik and Middle Himalayas, one of the most seismically active regions on earth. The geology and lithology of the area depict that the outer sedimentary belt in the study area includes the Krol belt while the inner belts constitute thick sequences of unmetamorphosed sediments. This area represents parts of the Lesser Himalayan Sequence (LHS) between the Main Boundary Thrust (MBT) and the Deoban Hill located North of Chakrata town. There are seven geological formations found in the study area, of which the Jaunsar group is the predominant formation that covers more than $90 \%$ of the geographical area. The whole terrain of the study area has a very rugged topography with altitude varying from $433 \mathrm{~m}$ near Yamuna River and $2456 \mathrm{~m}$ near Chakrata town $($ mean $=1445 \mathrm{~m}$, std. dev. $=585 \mathrm{~m})$. The area under present investigation forms a part of the Toposheet No. 53 F/14 and 53 F/15 of the Survey of India.

The study area typically experiences three seasons. The winter season extends from November to February, while the summer months in the area starting in March continue till May. By June, the rainy season begins in this hilly terrain, and it ends in September. The average annual rainfall in the area varies between $1,339 \mathrm{~cm}$ and $1,479 \mathrm{~cm}$. The minimum and maximum temperatures range from $1.4{ }^{\circ} \mathrm{C}$ in winter to $34^{\circ} \mathrm{C}$ in summer, with an average annual rainfall of about $1,400 \mathrm{~mm}$. The rainy season is quite intense, and the orographic rains in this Lesser Himalayan road corridor start in June. Often this area receives heavy rainstorms, sometimes cloudbursts, in July and August, which cause a lot of damage resulting in erosion, floods, and landslides.

According to National Bureau of Soil Survey (NBSS), India, the study area is covered by four distinct soil types namely- (i) moderately shallow, excessively drained, thermic, loamy skeletal soils on moderately steep slopes with loamy surface, moderate erosion and moderate stoniness (found mainly in summits and ridge tops); (ii) moderately deep, excessively drained, thermic, loamy skeletal soils on moderately steep slopes with loamy surface and moderate erosion (found in side slopes); (iii) moderately deep, well drained, thermic coarse loamy soils on moderate slopes with loamy surface and moderate erosion (found in fluvial valleys); and (iv) moderately shallow, excessively drained, thermic, coarse loamy soils on steep slopes with loamy surface, moderate erosion, and strong stoniness (found in side slopes). Agriculture, social forestry, and mining activities are amongst the main occupation of the villagers. Sahiya and Kalsi are the two major markets from where the fruits and vegetables produced have been transported to the nearby wholesale market in Saharanpur, further connected with the large vegetable market of Delhi.

\section{MATERIALS AND METHODS}

\section{Data acquisition and preparation}

In this study, three cloud-free satellite images, two acquired from Landsat 7 Enhanced Thematic Mapper Plus $\left(\mathrm{ETM}^{+}\right.$) series from the USGS (United States Geological Survey) and one from Resourcesat-2 from the NRSC (National Remote Sensing Centre, India), were used for generation of the LULC maps for the year 2000, 2010 and 2019, respectively. These images were chosen based on their availability, resolution, and quality of the datasets. The Landsat images have 15m Panchromatic (Pan) and $30 \mathrm{~m}$ Multispectral Scanner (MSS) spatial resolution, while the Linear Imaging Self-Scanning System IV (LISS IV) image, being a latest sensor, has a better spatial resolution of $5.8 \mathrm{~m}$ (Table 1). The Landsat images were processed in ERDAS IMAGINE software to generate $15 \mathrm{~m}$ pan-sharpened mosaic for LULC 
Sur U., Singh P.: Assessment of landscape change of Lesser Himalayan road corridor of Uttarakhand, India

classification at a higher resolution. All the images were of the same month of the year for similar seasonal appearances.

Table 1: Detail of satellite data used and their sources

\begin{tabular}{|l|l|c|c|c|l|}
\hline $\begin{array}{l}\text { Thematic } \\
\text { Data }\end{array}$ & Satellite/Sensor & $\begin{array}{l}\text { Sensor, } \\
\text { Path/Row }\end{array}$ & $\begin{array}{l}\text { Spatial } \\
\text { Resolution (M) }\end{array}$ & $\begin{array}{l}\text { Date of } \\
\text { Acquisition }\end{array}$ & Data Sources \\
\hline LULC 2000 & Landsat 7 ETM ${ }^{+}$ & $146 / 39$ & $\begin{array}{l}\text { Pan 15m, } \\
\text { MSS 30m }\end{array}$ & 14.03 .2000 & $\begin{array}{l}\text { http://earthexplorer.usgs } \\
\text {.gov }\end{array}$ \\
\hline LULC 2010 & Landsat 7 ETM ${ }^{+}$ & $146 / 39$ & $\begin{array}{c}\text { Pan 15m, } \\
\text { MSS 30m }\end{array}$ & 10.3 .2010 & $\begin{array}{l}\text { http://earthexplorer.usgs } \\
\text {.gov }\end{array}$ \\
\hline LULC 2019 & $\begin{array}{l}\text { Resourcesat-2/ } \\
\text { LISS IV }\end{array}$ & $95 / 47$ & $5.8 \mathrm{~m}$ & 17.3 .2019 & $\begin{array}{l}\text { National Remote } \\
\text { Sensing Centre (NRSC), } \\
\text { India }\end{array}$ \\
\hline
\end{tabular}

Fig. 2: Photographs depicting overview of the landscape and LULC- (a) The landscape along the Kalsi-Chakrata road corridor; (b) Evidences of land degradation (open areas, scrubland, sparse vegetation); (c) Forest area near Chakrata town; (d) Rural settlement with Agricutural practices; (e) Widening of roads; (f) Debris slide near Amraha village

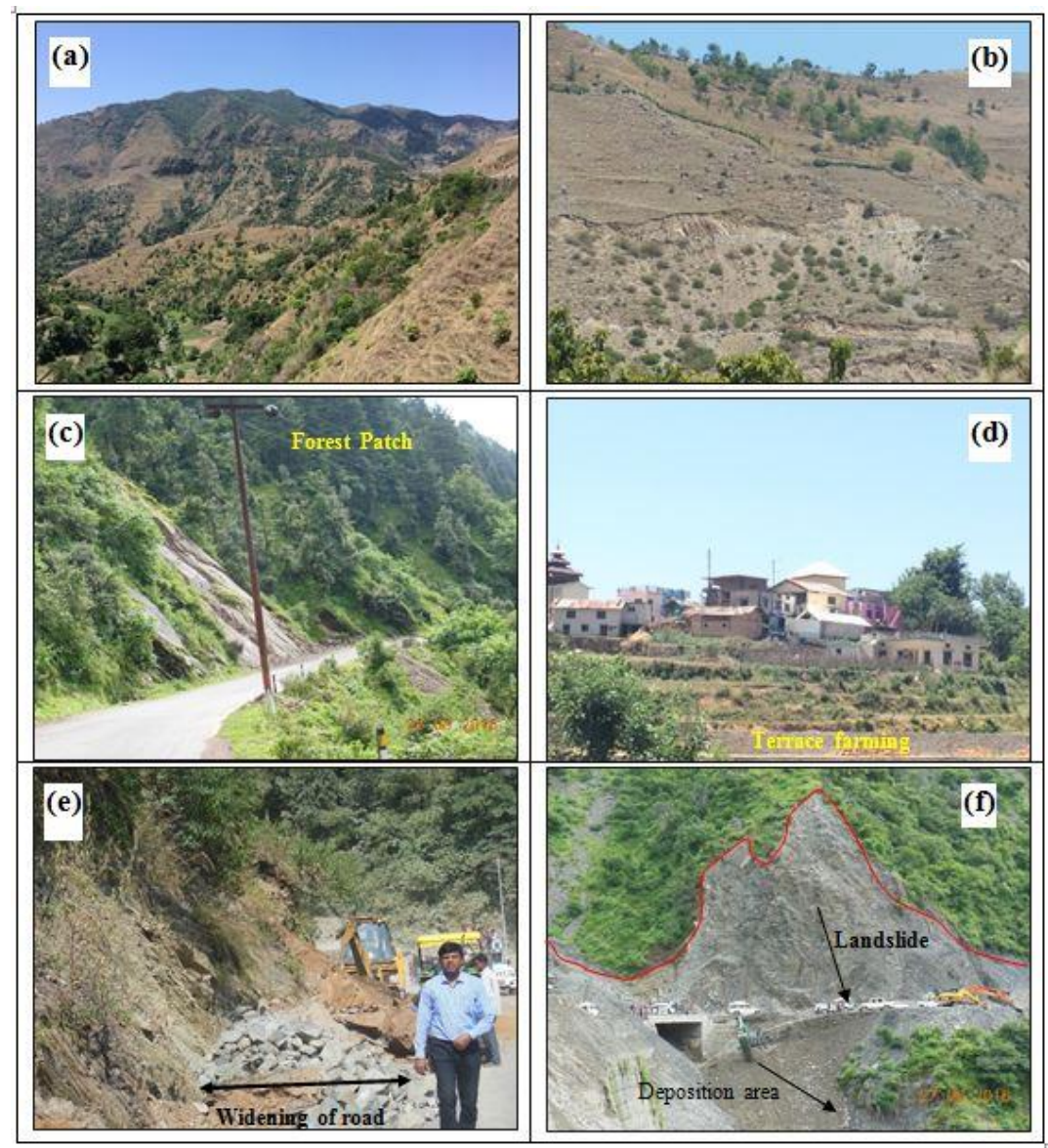


It was required to carry out digital image processing for atmospheric correction and reduce sensor variations as the study area is situated in the mountainous terrain (Jensen, 1996; Paolini et al., 2006; Chaudhuri \& Singh, 2018) using the ENVI5.1 software. For geometric registration, the 2019 LISS-IV image was georeferenced using the GCPs (ground control points) collected through GPS (Global Positioning System) and the DGPS (Differential GPS) points from the local authorities (Figure 2). Next, the Landsat images of 2000 and 2010 were matched and geometrically corrected in ArcGIS 10.3 software and projected at a common Universal Transverse Mercator (UTM) projection system (Zone 44N). Finally, the images were clipped to the study area for further classification.

\section{LULC classification and change detection}

For LULC mapping, an object-oriented hybrid classification technique was applied to categorize the pixels and geometric properties of the images for precise delineation of different landscape elements. Several studies have suggested using the hybrid classification approach over the unsupervised or supervised classification due to its superior results and ability to perform better for spectral variability of land-cover types (Garcia \& Alvarez, 1994; Mas, 1999; Xiao \& Weng, 2007).

To better understand the spatial occurrences of various LULC classes, the delineation of these classes was carried out through field data collection using GPS, ancillary information, and visual interpretation for each class. Next, all the images were segmented into homogenous regions by assigning per-pixel signatures and classified the images into nine distinct LULC classes by the specific digital numbers (DN) of different landscape elements. The training datasets were prepared by determining the polygons (10 -20 samples for each class) around the representative sites for each of these predetermined LULC classes based on visual analysis and field data. The training datasets with mixed spectral signatures were discarded, and new samples were considered to improve the classification. Afterward, the maximum likelihood classification (MLC) algorithm was applied for supervised image classification using the training datasets. By overlaying the hybrid classification results on the high-resolution satellite image, the post-classification refinement was carried out to improve the classification accuracy for required patches. Through this method, all the pixels that were classified incorrectly was rectified for the entire study area. The final delineated LULC classes were (i) forest, (ii) sparse vegetation, (iii) scrubland, (iv) agricultural land, (v) settlement area, (vi) rocky barren land, (vii) open area, (viii) sandy area and (ix) river/water bodies (Table 2).

The LULC change detection assessment was performed through overlay analysis identifying the areas changed from one particular LULC class to another over the past two decades. For this, the change-transition matrix was computed in ArcGIS software using the cross-tabulation module. The result presented the gains and losses in coverage areas by the main LULC classes for the past two decades.

Accuracy assessment is a critical aspect of validating the digitally classified LULC maps. Usually, the classification output is compared against the geographical reference data representing the true landscape elements at a given space and time. The reference data used is acquired from two sources, (i) field visits and collection of "ground truth" guided by GPS at the identified sites across the study area; (ii) visual interpretation of LULC classes from satellite images. The stratified random methods were adopted for all the three LULC maps to represent different LULC categories, and accuracy was estimated using 30 pixels for each of them. An error matrix was generated by cross-tabulation of the LULC class values and the ground truths in the form of user's and producer's accuracy. Finally, the accuracy statistics have been presented in the form of overall accuracy and non-parametric Kappa coefficient. 
Sur U., Singh P.: Assessment of landscape change of Lesser Himalayan road corridor of Uttarakhand, India

Table 2: LULC classification scheme

\begin{tabular}{|l|l|}
\hline \multicolumn{1}{|c|}{ Class } & \multicolumn{1}{c|}{ Descriptions } \\
\hline Urban built-up area & $\begin{array}{l}\text { Built-up area (both compact and sparse) comprising of residential, commercial, } \\
\text { residential-cum-commercial settlement clusters }\end{array}$ \\
\hline Rural built-up area & Rural built-up areas \\
\hline Forest area & $\begin{array}{l}\text { Dense/closed and open category of evergreen/Semi-evergreen/closed deciduous trees, } \\
\text { natural forest and plantation forest }\end{array}$ \\
\hline Agricultural land & Crop fields and fallow lands including current shifting cultivation \\
\hline Sparse vegetation cover & Grassland, open category of deciduous and tree clad area \\
\hline Barren rocky land & Barren rocky areas including rock outcrops \\
\hline Sandy area & Riverine sandy area \\
\hline Scrubland & Dense/closed and open category of scrubland \\
\hline Open area & The areas having exposed soil and barren area influenced by human, wasteland \\
\hline River/ water bodies & Perennial \& non-perennial river and streams, Permanent \& seasonal lake/ ponds \\
\hline
\end{tabular}

\section{RESULTS}

\section{Accuracy assessment}

The accuracy assessment for the LULC output was carried out through an error matrix with the user's accuracy, producer's accuracy, and kappa indices. To estimate the overall accuracy, the correctly classified pixels were divided by the total number of pixels, and it ranged from $95.55 \%$ to $97.63 \%$, with Kappa indices of agreement ranging from 0.88 to 0.94 for the year 2000, 2010 and 2019 (Table 3). The LULC classification results are found acceptable for the study as they satisfy the minimum $85 \%$ accuracy level (Anderson, 1976).

Table 3: Accuracy assessment of LULC

\begin{tabular}{|c|c|c|c|c|c|c|}
\hline \multirow[b]{2}{*}{ LULC } & \multicolumn{2}{|c|}{2000} & \multicolumn{2}{|c|}{2010} & \multicolumn{2}{|c|}{2019} \\
\hline & PA & UA & PA & UA & PA & UA \\
\hline Settlement area & 96.30 & 75.36 & 95.96 & 90.48 & 95.83 & 89.84 \\
\hline Agriculture & 99.04 & 99.68 & 99.57 & 99.02 & 100 & 99.51 \\
\hline Forest & 98.68 & 99.78 & 96.77 & 97.61 & 98.68 & 100 \\
\hline spares Veg & 92.94 & 87.78 & 82.42 & 90.91 & 97.26 & 84.52 \\
\hline Sandy Area & 100 & 94.86 & 97.66 & 99.64 & 100 & 99.62 \\
\hline Barren Rocky & 100 & 100 & 99.01 & 99.01 & 100 & 100 \\
\hline Scrub Land & 97.01 & 96.30 & 99.72 & 97.25 & 97.88 & 91.38 \\
\hline Open Area & 89.25 & 100 & 86.36 & 78.30 & 68.85 & 94.56 \\
\hline River \& Waterbody & 87.50 & 100 & 96.39 & 79.21 & 94.12 & 100.00 \\
\hline Overall Accuracy (\%) & \multicolumn{2}{|c|}{97.61} & \multicolumn{2}{|c|}{95.55} & \multicolumn{2}{|c|}{97.63} \\
\hline Kappa & \multicolumn{2}{|c|}{0.91} & \multicolumn{2}{|c|}{0.88} & \multicolumn{2}{|c|}{0.94} \\
\hline
\end{tabular}




\section{LULC change}

The LULC change detection results have been summarized in Table 4 for the past two decades (2000 to 2019). Besides, Figure 3 presents the spatial distribution of LULC classes along with a bar chart showing the $\%$ distribution of the areas under different classes. From Figure 3, it has been observed that in 2000, forest area was the dominant LULC class covering $47.40 \%$ of the total study area, followed by sparse vegetation $(25.06 \%)$, open area $(18.27 \%)$, scrubland $(4.25 \%)$, agriculture $(2.96 \%)$, river and waterbody $(1.35 \%)$, Settlements $(0.33 \%)$, sandy area $(0.20 \%)$ and barren rocky areas $(0.17 \%)$. During the past two decades, the forest cover in the study area decreased from $39.12 \mathrm{sq} . \mathrm{km}$. $(47.40 \%)$ in 2000 to 30.27 sq. km. (36.68 \%) in 2019 (Table 4). It suggests an overall decrease in forest cover was reduced by about $10.72 \%$, which means an annual rate of change of $-0.56 \%$ per year. Among the other LULC classes that showed a decreasing trend between 2000 and 2019 were sparse vegetation (-8.37\%), and river \& waterbodies (-0.56\%). Conversely, during this period, the open areas and agricultural areas increased by $14.32 \%$ and $4.50 \%$, respectively. The built-up areas (urban and rural settlements) were progressively increased from $0.33 \%$ in 2000 to $0.56 \%$ in 2019. From Table 4, it was further observed that as a whole, the land-cover classes in the study area had been declined by $4.73 \%$, which was contained by the land-use classes. 


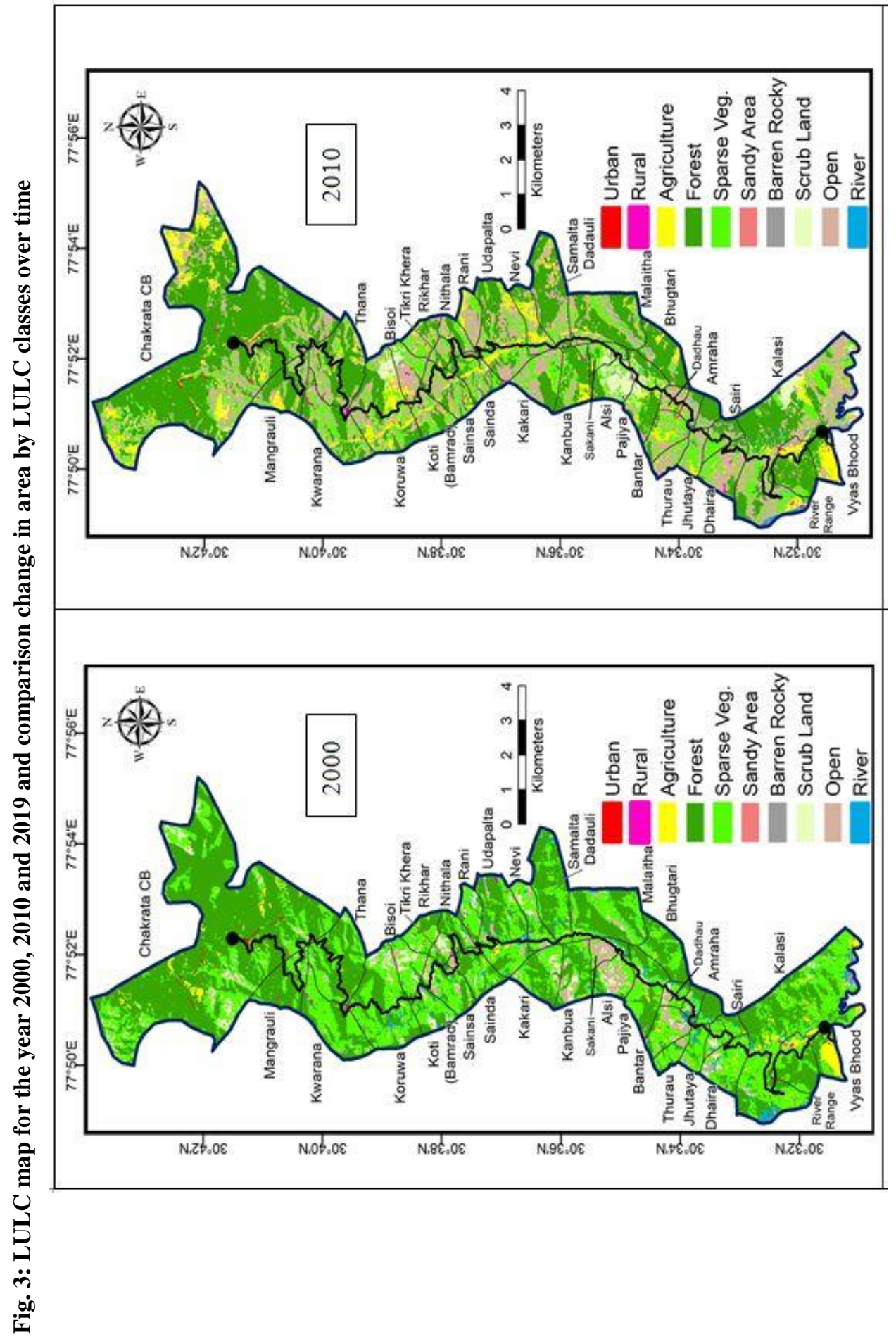




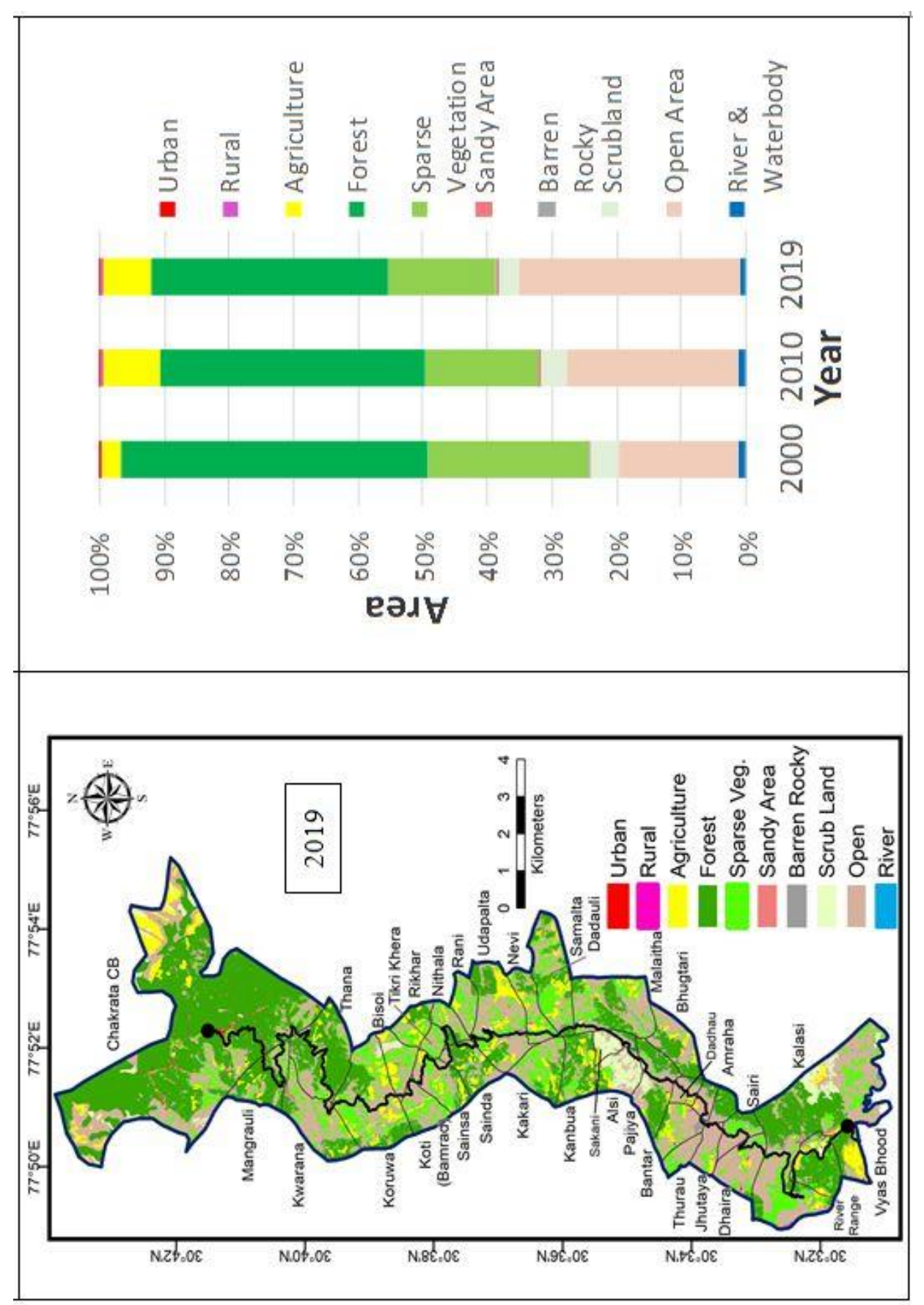




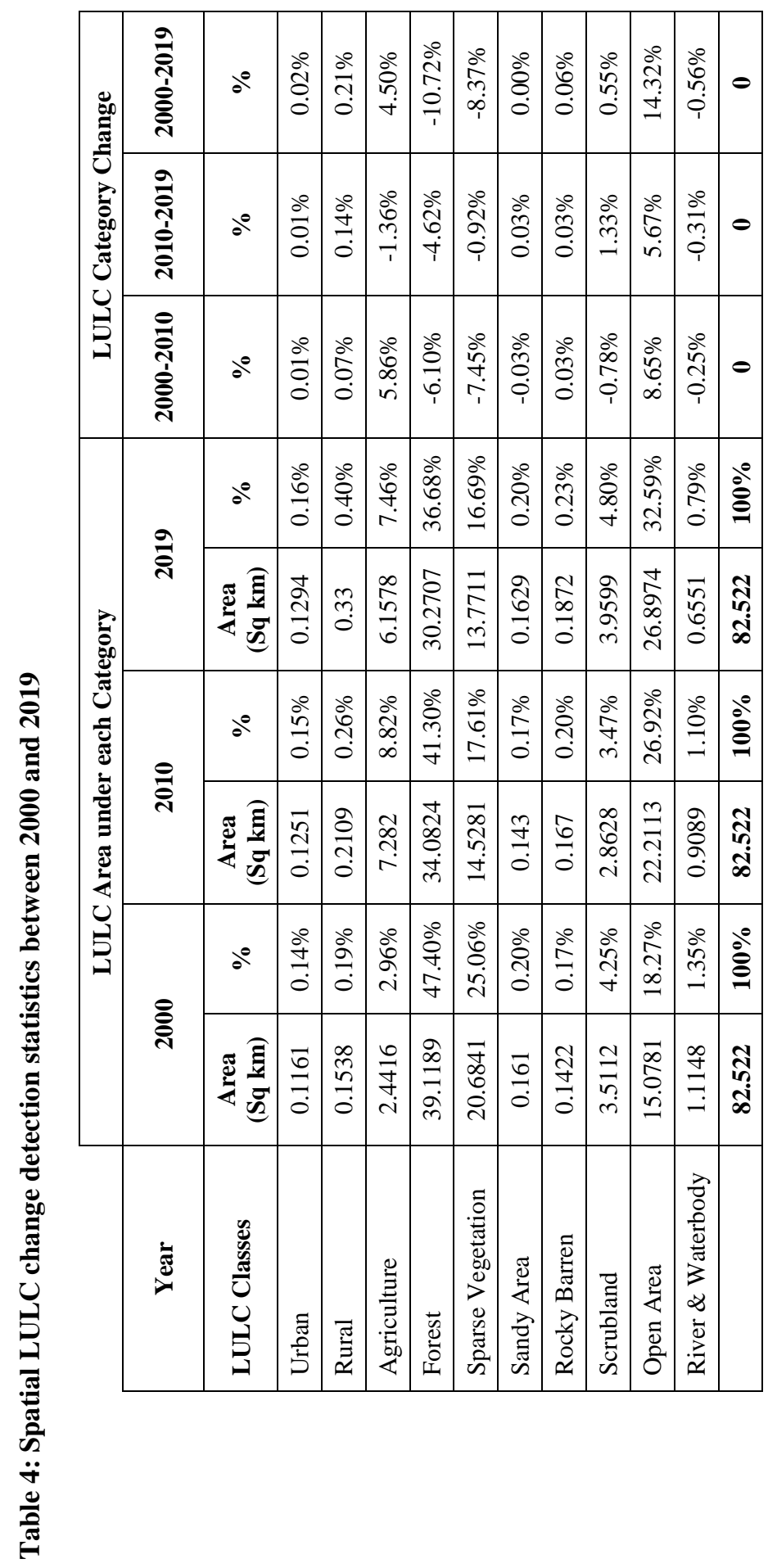




\section{LULC trends}

The LULC change trends were represented by a transition matrix that was prepared based on cross-tabulation that indicates the LULC class areas with their corresponding percentages that were transformed into another class from 2000 to 2019. From Table 5, no change in urban settlements was observed, and the urban built-up areas remained approx. $100 \%$ intact concerning the total area of the LULC class, followed by rocky barren (96\%) and rural settlement (94\%), agriculture $(86 \%)$ and river/waterbody $(83 \%)$. The highest conversion was observed in the sparse vegetation area, where about $27 \%$ of its total area was transformed into the open areas while $11 \%$ was into scrubland. As illustrated in the above section, the forest cover was depleted very fast and converted to sparse vegetation (19\%), open area $(7 \%)$, agriculture $(3 \%)$, and scrubland $(3 \%)$ with respect to the total areas under the forest class. The spatial change in occurrence among the land-cover classes of the forest, sparse vegetation, scrubland, and open area LULC class was observed. However, there was less conversion of the agricultural land, and about $8 \%$ of the sandy areas from 2000 were transformed into this category, which may be associated with the plantation and cultivation along the seasonal streams and their beds. As a whole, during the studied period, the forest cover (2.27 sq. km.), sparse vegetation (3.26 sq. km.) and scrubland ( $0.65 \mathrm{sq}$. km.) classes which together constitute about $6.2 \mathrm{sq}$. $\mathrm{km}$. were converted to open areas. Moreover, about $6.2 \mathrm{sq}$. km. of forest land was converted to sparse vegetative cover. This trend of LULC transition has been illustrated using the Sankey diagram for the period 2000 to 2010 and 2010 to 2019 (Figure 4). In the figure, the transition is colorized to trace how the LULC has changed dynamically over time visibly. The rapid conversion of the forest areas into other LULC classes is highly significant. Such a trend of LULC change requires considerable attention from the local authorities and environmental conservation agencies.

At the village level, the change in the dominant LULC classes was analyzed. In 27 villages out of total 34, the forest cover was reduced, varying from $1.74 \%$ to $39.02 \%$ of the respective village geographical areas. Samalta Dadauli village has shown maximum transition of forest land (-39.02 \%) into the open areas (17.86\%), agricultural land (10.69 \%), and sparse vegetation (10.29\%) classes. The other villages having a considerable amount of forest land transformation are Nithala (33.59\%), Bhugtari $(27.86 \%)$, Udapalta (25.66 \%), Malaitha $(24.11 \%)$, Koti (Bamrad) $(23.75 \%)$ and Kakari $(20.87 \%)$. In the majority of the villages, the sparsely vegetative areas were observed converted to open areas. For example, Jhutaya and Dhaira villages have shown open areas increased by $63.42 \%$ and $62.57 \%$ of the respective village areas, respectively, mainly because of the conversion of the sparse vegetation into open areas. Among the land-use classes, agricultural land in 


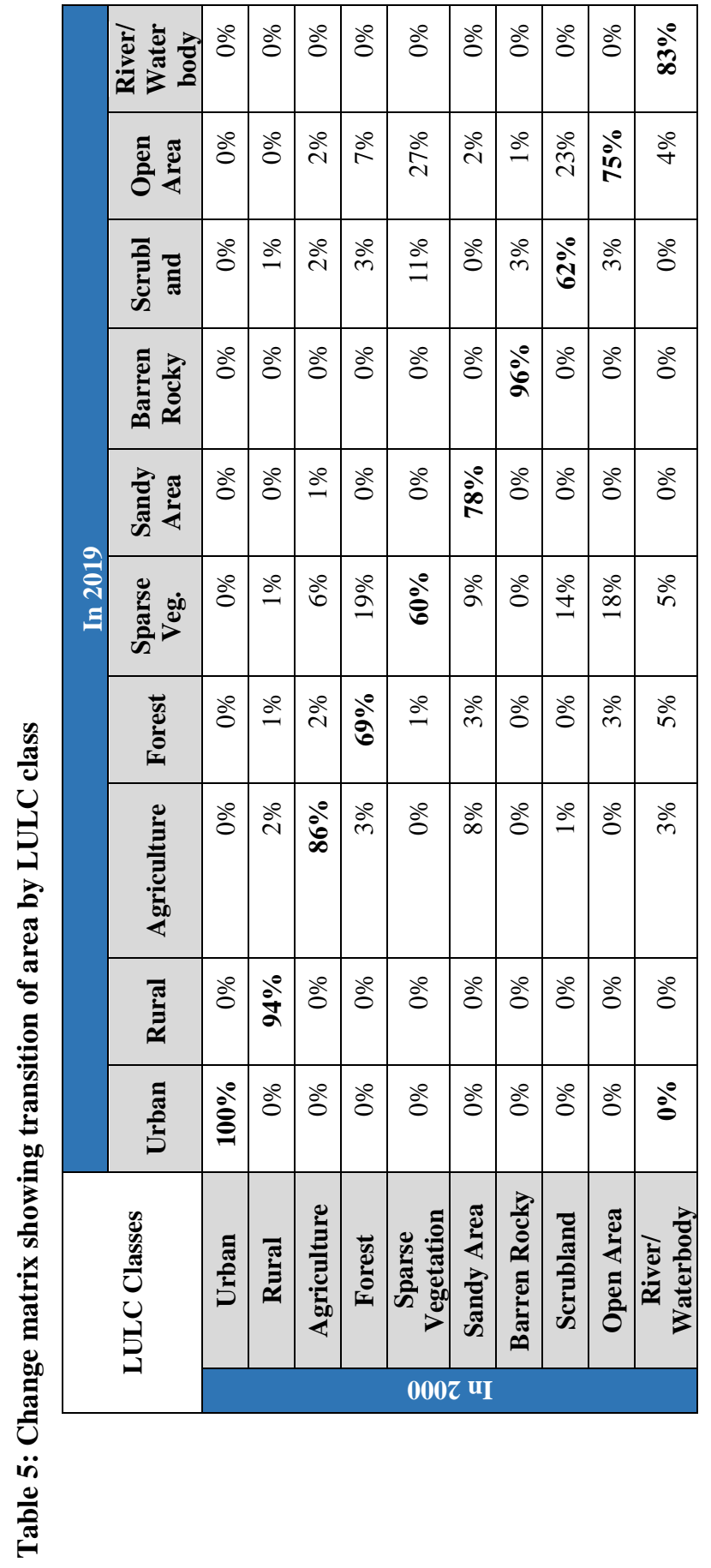

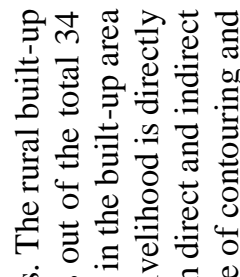

$\dot{0} 0:=5$

递要 品.

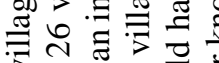

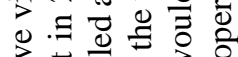

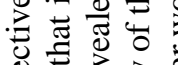
¿

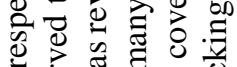
$\Rightarrow$ 可

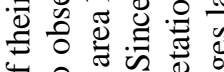
to 0 in 。 ส 은 击

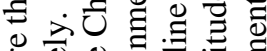

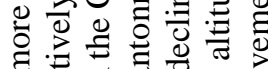

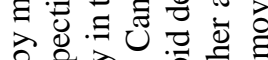

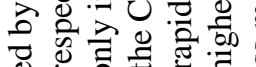
可 की

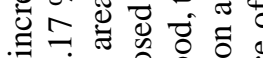

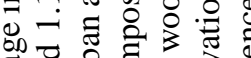

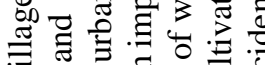
5 年

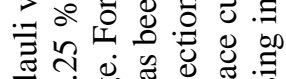

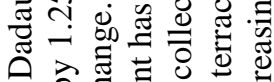

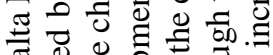

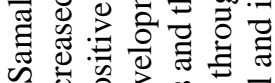
氙. 䨌

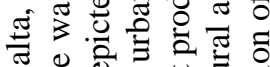

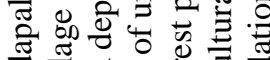

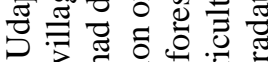
की

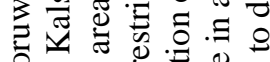

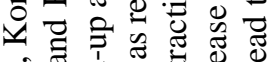

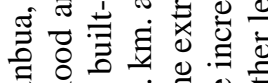

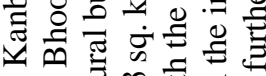

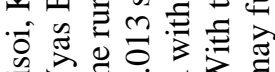

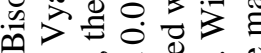

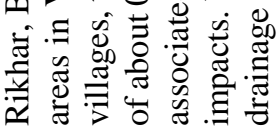


Fig. 4: Sankey diagram showing transition of LULC classes (a) 2000-2010; (b) 2010-2019

a) $2000-2010$

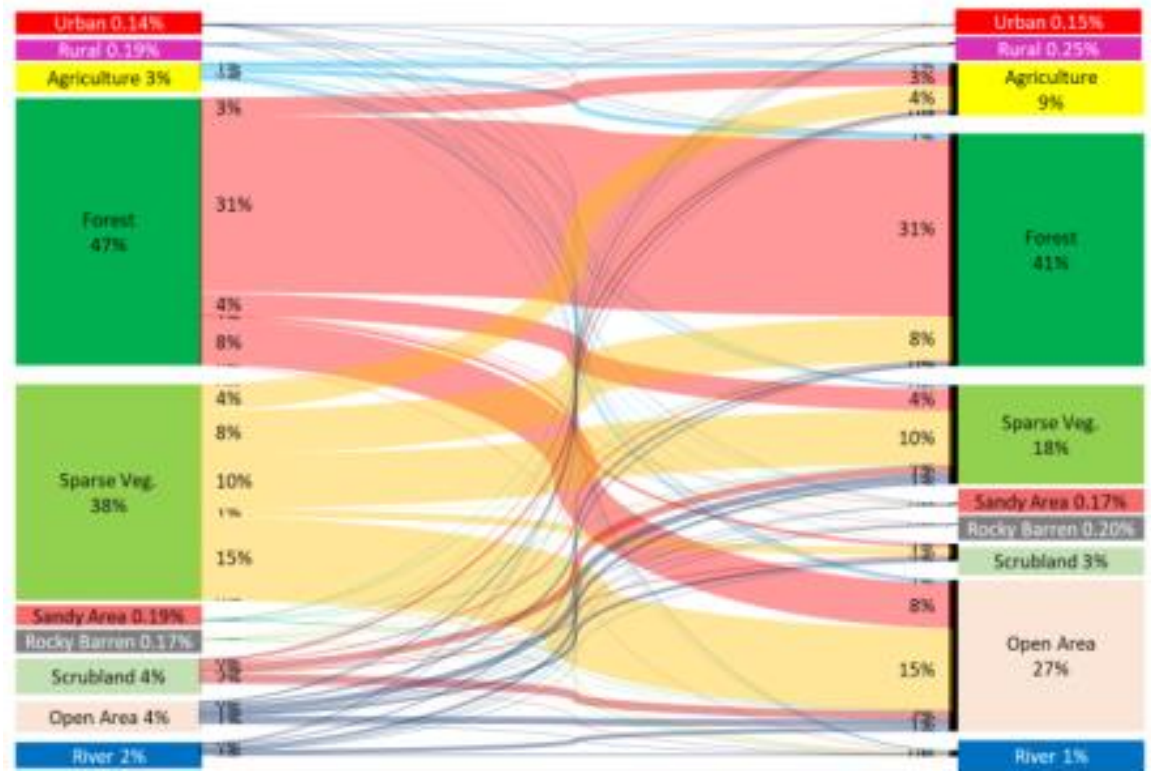

b) 2010 - 2019

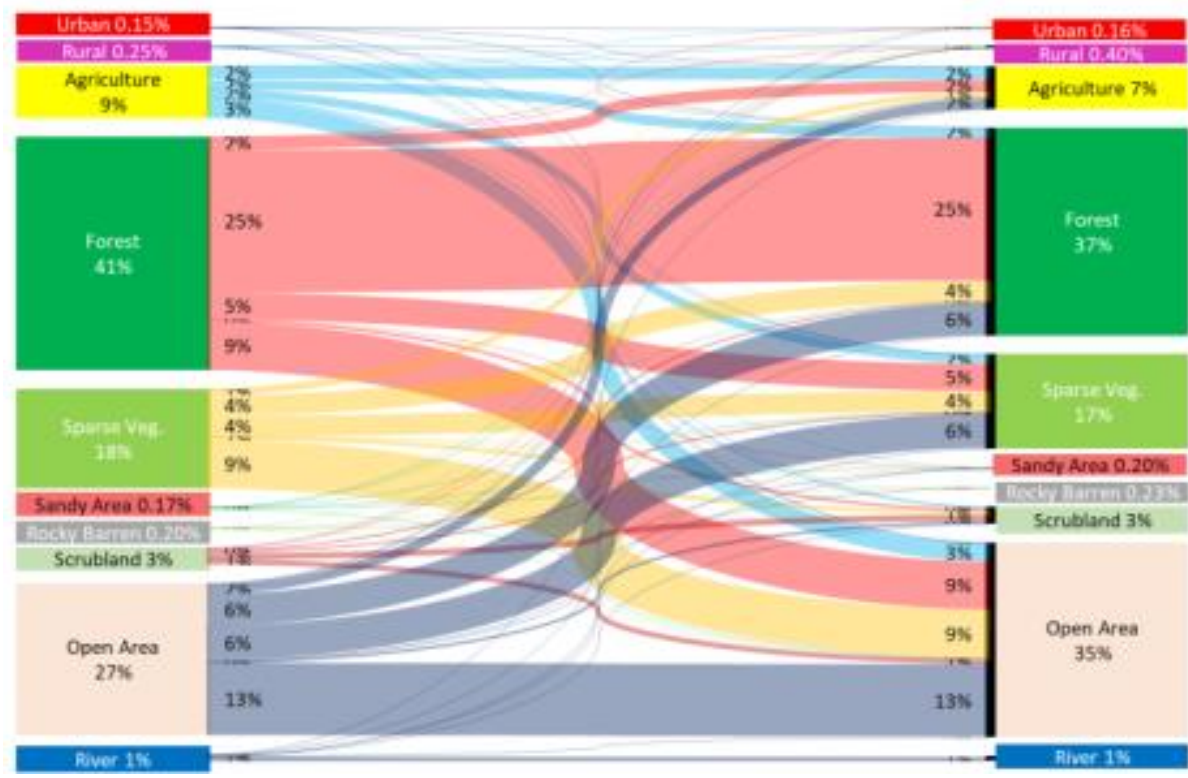


Sur U., Singh P.: Assessment of landscape change of Lesser Himalayan road corridor of Uttarakhand, India

Table 6: Spatial Change in LULC area by villages under each category

\begin{tabular}{|c|c|c|c|c|c|c|c|c|c|c|c|}
\hline SN. & NAME & Urban & Rural & Agriculture & Forest & $\begin{array}{l}\text { Sparse } \\
\text { Veg. }\end{array}$ & $\begin{array}{l}\text { Snady } \\
\text { Area }\end{array}$ & $\begin{array}{l}\text { Barren } \\
\text { Rocky }\end{array}$ & Scrubland & Open Area & $\begin{array}{c}\text { River/ } \\
\text { Waterbody }\end{array}$ \\
\hline 1 & Samalta Dadauli & - & 0.15 & 10.69 & $39.02)$ & 10.29 & $(0.06)$ & - & 0.13 & 17.86 & $(0.03)$ \\
\hline 2 & Nithala & - & 0.12 & 3.37 & $33.59)$ & $(1.51)$ & $(0.12)$ & - & $(7.16)$ & 38.88 & 0.01 \\
\hline 3 & Bhugtari & - & 0.11 & 7.29 & (27.86) & (24.97) & - & - & $(0.06)$ & 45.65 & $(0.16)$ \\
\hline 4 & Udapalta & - & $(0.15)$ & 11.29 & $25.66)$ & (19.24) & 0.31 & - & $(1.88)$ & 35.33 & $(0.01)$ \\
\hline 5 & Malaitha & + & 0.17 & 3.94 & 24.11) & (17.44) & $(0.13)$ & - & $(1.48)$ & 39.07 & $(0.02)$ \\
\hline 6 & Koti (Bamrad) & - & - & 4.03 & $23.75)$ & $11.75)$ & (1.04) & - & $(12.28)$ & 44.80 & $(0.02)$ \\
\hline 7 & Kakari & - & 0.06 & 5.32 & $20.87)$ & $(6.40)$ & $(0.11)$ & - & $(8.44)$ & 30.51 & $(0.07)$ \\
\hline 8 & Tikri Khera & + & 0.02 & 0.69 & $20.45)$ & 15.02 & - & - & 23.43 & 28.15 & - \\
\hline 9 & Sainsa & + & 0.21 & 10.31 & 19.01) & $15.59)$ & $(0.17)$ & - & $(7.85)$ & 32.08 & 0.02 \\
\hline 10 & Kwarana & + & 0.18 & 3.67 & $18.53)$ & $31.05)$ & $(0.07)$ & - & $(1.62)$ & 47.42 & - \\
\hline 11 & Thurau & + & 0.02 & $(2.32)$ & 17.52 & $29.82)$ & - & (D.05) & $(1.19)$ & 51.09 & $(0.20)$ \\
\hline 12 & Koruwa & + & 0.11 & 11.40 & $15.89)$ & (20.40) & $(0.07)$ & - & $(6.14)$ & 31.00 & - \\
\hline 13 & Jhutaya & + & - & 4.58 & $14.30)$ & 52.12 & - & (D.07) & $(1.26)$ & $\begin{array}{l}63.42 \\
\end{array}$ & $(0.25)$ \\
\hline 14 & Rani & + & - & 10.07 & $14.08)$ & (18.28) & (1.63) & - & $(11.60)$ & 35.53 & - \\
\hline 15 & Mangrauli & + & 0.32 & 4.88 & $13.35)$ & (16.10) & - & - & $(1.89)$ & 26.11 & 0.03 \\
\hline 16 & Dhaira & + & 0.49 & $(1.27)$ & $11.55)$ & $38.85)$ & $(0.57)$ & (3.15) & $(7.55)$ & \begin{tabular}{|l|l}
62.57 \\
\end{tabular} & $(0.13)$ \\
\hline 17 & Bisoi & + & 0.58 & 16.47 & 10.86) & $25.10)$ & $(0.08)$ & - & 13.39) & 32.38 & - \\
\hline 18 & Bantar & + & 0.40 & 8.64 & $10.85)$ & 26.13) & - & - & $(5.00)$ & 32.96 & $(0.02)$ \\
\hline 19 & River Range & 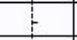 & 0.18 & $(4.43)$ & 10.41) & (28.89) & 0.45 & (D.10) & 5.10 & 38.11 & $(0.02)$ \\
\hline 20 & Rikhar & + & 0.28 & 16.79 & 10.04 & (21.59) & $(0.09)$ & - & $(5.85)$ & 20.57 & $(0.07)$ \\
\hline 21 & Chapanu & - & 0.12 & 3.36 & $10.00)$ & $27.72)$ & (1.05) & (b.30) & $(8.06)$ & $\begin{array}{l}43.77 \\
\end{array}$ & $(0.10)$ \\
\hline 22 & Sairi & + & - & (3.69) & $(7.15)$ & $29.45)$ & (1.01) & - & $(7.24)$ & 48.88 & $(0.34)$ \\
\hline 23 & Amroha & + & - & $(0.71)$ & $(5.75)$ & (12.69) & - & p.05 & - & 19.56 & $(0.46)$ \\
\hline 24 & Chakrata CB & d.06 & 0.26 & 4.20 & $(4.39)$ & 18.83) & $(0.01)$ & - & $(1.10)$ & 19.82 & 0.00 \\
\hline 25 & Alsi & - & 0.05 & 6.69 & $(3.41)$ & $34.00)$ & $(0.07)$ & - & 84.00 & $(3.20)$ & $(0.07)$ \\
\hline 26 & Dadhau & + & 0.45 & 6.60 & (2.54) & 41.79 & - & (p.02) & (11.27) & 51.68 & (3.12) \\
\hline 27 & Sakani & 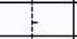 & - & 4.28 & $(1.74)$ & (24.04) & $(0.12)$ & - & $\$ 1.64$ & $(9.65)$ & $(0.36)$ \\
\hline 28 & Nevi & 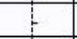 & 0.56 & 10.36 & 0.33 & (25.68) & $(0.06)$ & - & $(9.09)$ & 23.58 & - \\
\hline 29 & Sainda & + & 0.25 & 8.36 & 0.91 & $31.26)$ & 0.76 & - & $(5.36)$ & 26.35 & $(0.01)$ \\
\hline 30 & Pajiya & 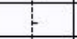 & $0.11)$ & 0.35 & 1.66 & $34.85)$ & - & - & 4.65 & 28.31 & - \\
\hline 31 & Thana & + & 0.08 & 4.83 & 2.54 & $27.68)$ & - & - & $(2.41)$ & 22.65 & $(0.01)$ \\
\hline 32 & Vyas Bhood & d.02 & 1.25 & $(6.86)$ & 3.53 & (16.06) & - & - & - & 18.12 & - \\
\hline 33 & Kanbua & + & 0.09 & 11.62 & 5.47 & $12.37)$ & $(0.11)$ & - & $(8.14)$ & 3.44 & - \\
\hline 34 & Kalasi & 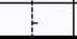 & 1.17 & 3.34 & 6.25 & $23.67)$ & 1.82 & - & - & 11.10 & - \\
\hline
\end{tabular}

The above analysis depicts that the Kalsi-Chakrata area has experienced a considerable amount of LULC change over the past two decades, with a significant decline in forest cover and expansion of land use classes and bare lands. The LULC trends presented through the transition matrix show the transformation of LULC classes into other categories and helped assess the drivers of LULC change and the potential future trajectories. The village areas' rapid transition from predominant land cover to land use classes or bare lands is a serious concern, particularly for the villages situated at a lesser altitude between Sahiya and Kalsi. The time series output through RS and GIS technique in the form of LULC maps are found useful for assessing the patterns and transformation in the landscape, such as the demarcation of the areas where LULC changes are rapid and extensive leading to ecological and environmental vulnerabilities in the Lesser Himalayas. 


\section{DISCUSSION}

The study results show significant transformation in land-use and land cover along the Kalsi-Chakrata road corridor between 2000 and 2019. As presented in the introduction section of this paper, the change in LULC is fundamentally determined by ecological conditions, morphology, and climate, along with anthropogenic activities such as socio-economic development, transportation practices, and institutional set-up. In some areas, the LULC is observed to be rapidly transformed from one category to another due to population growth, urbanization, and industrialization (Rai et al., 1994; Voogt \& Oke, 2003). Though conversion of land cover areas due to land-use practices do not inevitably result in the degradation of land, however, LULC changes affect the geo-environmental processes and natural ecosystems such as biodiversity, water, etc. (Riebsame et al., 1994; Pauleit et al., 2005; Yang et al., 2017). In this study, the LULC change analysis indicates that forest cover, the main land cover class, was intensively converted to open areas, sparse vegetation, and different land-use categories such as agricultural land, built-up areas. The LULC trend analysis results show that the forest cover in the study area decreased from $47.27 \%$ in 2000 to $36.66 \%$ in 2019. During the same period, the open areas and agricultural areas were increased by $15.86 \%$ and $4.49 \%$, respectively. Moreover, the built-up areas (both urban and rural settlements) was progressively increased from $0.33 \%$ in 2000 to $0.56 \%$ in 2019 . The increase in built-up areas indicates an increase in population in the study area, which is evident from the Census of India 2000-2011 data. The forests and sparsely vegetative areas were converted to agricultural land and rural settlements as their spatial variations are often induced or controlled by various anthropological activities. The result of this study concurs with the other studies conducted in the Himalayan region of India (Rao \& Pant, 2001; Yu et al., 2007; Pandit et al., 2007; Sharma et al., 2016; Bartar et al., 2017). The high dependence of the local community on forest products as part of the livelihood, increase in the agricultural practices, and extraction of natural resources may be interrelated with the general decrease in the dense vegetation cover in the area. Similar cases of the decline in the forest cover have also been reported in other studies (Tiwari 2000; FSI, 2004; Sharma et al., 2007; Yu et al., 2007). The loss of forest cover in the Himalayan mountain region is correlated with the increasing natural hazards such as floods, landslides, avalanches, etc. The loss of vegetation cover stabilizes the soil and improves the slope stability through the plant root system. The occurrences of the frequent landslides along the Kalsi-Chakrata road corridor may be connected with the trend of LULC change in association with the rugged terrain, complex and fragile hydro-geomorphological settings, and increasing intensity of Monsoon rainfall (Sur \& Singh 2019, Sharma et. al., 2020). Therefore, there is a need to investigate and further establish the relationship between LULC and the natural hazards in the Lesser Himalayan terrain.

Although the present study considers a small road corridor as a test area, the findings are significant and promising because it could establish the correlation between the transformation of areas under different LULC classes. The increased human interference on the land cover through road widening, increased vehicular movements, extension of agriculture, and mining in the study area indicates a further decrease in the forest cover in the near future. The increase in open areas resulting from a reduction of forest cover and sparse vegetation suggests an increase in the non-forest land and wasteland, which could lead to loss of topsoil cover, increased surface run-off, and reduced groundwater recharge. The rapid and drastic change of LULC cover at the village level is very significant from the rural communities' livelihood and the sustainable development of the area. Such changes are more prominent in the villages located at the lower altitude between Kalsi and Sahiya town. In villages, namely Samalta Dadauli, Nithala, Bhugtari, and Udapalta reported maximum 
Sur U., Singh P.: Assessment of landscape change of Lesser Himalayan road corridor of Uttarakhand, India

transition of forest areas into the open area, agricultural land, and sparse vegetation. Further, the villages where open areas have been increased by more than $50 \%$ in two decades are Jhutaya and Dhaira, mainly due to the conversion of the sparsely vegetated areas. The decreasing trend of areas under water bodies/rivers in some of the villages indicates the possible scarcity of water, which could link with the incidence of climatic or seasonal variation over the period. Extending the outcome of LULC trend analysis at the village level opens the path for a detailed investigation to study the probable impact of climate change in the Lesser Himalayan terrain in relation to the hydro-geomorphic and anthropogenic processes which could comprehensively lead to the sustainable development at a local scale.

\section{CONCLUSION}

In this study, we pursue to understand how the characteristics of different LULC classes changed quantitatively through the overall development and land distribution using time series maps. The use of cost-effective LULC change analysis through remote sensing satellite imagery and integrated GIS technique made it possible to quantify, map, and spatially correlate the changing pattern in LULC in villages of the Kalsi-Chakrata road corridor for 17 years. The study area experienced a significant decline in forest cover $(-10.72 \%)$, followed by sparse vegetation $(-8.37 \%)$ and river \& water bodies $(-0.56 \%)$. In comparison, there was a considerable increase in the open areas $(+14.32 \%)$, agricultural land $(+4.50 \%)$, scrubland $(+0.55 \%)$, and the built-up area $(+0.23 \%)$ between 2000 and 2019 which advocate for a gradual change in the LULC pattern. The reduction of forest cover and an increase in land-use activities are salient feature of the area which is likely to decrease the forest cover further due to commercial activities of resources, spreading out of agricultural land and growth of built-up areas. This indicates the upsurge of areas under the land-use classes was the result of population growth, mining activities and increased vehicular movements which have implications for biodiversity and ecosystem, especially in the middle and lower part of the study area. The increase in agricultural land at higher altitude areas near the Chakrata indicates increase in terrace cultivation through clearing of forest areas which may have multiple implications and requires more detailed investigation. Significantly, the trees and bushes need to be preserved not only to stabilize slopes but for the added benefit of habitat for wildlife. Finding areas where conversion was rapid will help to prioritize and fill such gaps through forest management, biodiversity strategies and necessary conservation.

Further, analyzing and mapping the LULC change trend at village level provides a strong basis for strategic planning, addressing environmental issues and sustainable decision making. The improved understanding and study of the salient drivers in the Lesser Himalayan road corridors can assist to recognize the underlying forces of LULC change and extend the investigation to other areas at different scale. Such an approach would help understand how the current land-use practices and anthropogenic factors affect the landscape change and from the acquired result, we can infer that a detailed spatial study of the landscape is a primary requisite for proper site selection for developmental activities. The present study can help unlock the future scope to investigate the complex interconnection between ecological and social changes under the influence of climate change in the mountainous rural landscape in the Lesser Himalayas, which is vital for land management and landscape sustainability. 


\section{REFERENCES}

Alves, D. S. and Skole, D. (1996). Characterizing land cover dynamics using multi-temporal imagery. Int. J. Remote Sen. 17 (4), 835-839. DOI: 10.1080/01431169608949049.

Arficho, M. and Thiel A. (2020). Does Land-Use Policy Moderate Impacts of Climate Anomalies on LULC Change in Dry-Lands? An Empirical Enquiry into Drivers and Moderators of LULC Change in Southern Ethiopia. Sustainability, Vol. 12, 6261. doi:10.3390/su12156261.

Bartar, A. K., Watanabe, T., Kumar, A. (2017). Assessment of Land-Use/Land-Cover Change and Forest Fragmentation in the Garhwal Himalayan Region of India. Environments 2017, 4, 34; doi:10.3390/environments4020034.

Brandt. J. and Townsend, T.A. (2006). Land Use - Land Cover Conversion, Regeneration and Degradation in the High Elevation Bolivian Andes. Landscape Ecology 21(4):607-623. DOI: $10.1007 / \mathrm{s} 10980-005-4120-\mathrm{z}$.

Carlson, T.N. and Azofeifa, S.G.A. (1990). Satellite Remote Sensing of land Use changes in and around SanJose. Costa Rica. Remote Sensing of Environment. 70 (3): 247-256. DOI: 10.1016/S0034-4257(99)00018-8.

Chaudhuri, A., Singh, P., Rai, S. C. (2018). Modelling LULC change dynamics and its impact on environment and water security: Geospatial technology based assessment. Ecology, Environment and Conservation. 24: pp. (S292-S298).

Coppin, P., Jonckheere, I., Nackaerts, K., Muys, B., Lambin, B. (2004), Digital change detection methods in ecosystem monitoring: A review. Int. J. Remote Sens. 25, 1565-1596. DOI: $10.1080 / 0143116031000101675$.

Daniel, L. C., James, D. H., Emily, H. W., Mingjun, S., Zhenkui, Z. (2002). A Comparison of Land use and Land Cover Change Detection Methods. ASPRSACSM Annual Conference and FIG22nd Congress, p. 2.

Dwivedi, R.S., Sreenivas K., Ramana, K.V. (2005). Landuse/land-cover change analysis in part of Ethiopia using Landsat Thematic Mapper data. International Journal of Remote Sensing. 26(7):1285-1287. DOI: 10.1080/01431160512331337763.

Forest Survey of India (FSI) (2004). India State of Forest Report; Ministry of Environment and Forests: Dehradun, India, 2004.

Garcia, M. and Alvarez, R. (1994). TM digital processing of a tropical forest region in southern Mexico. Int. J. Remote Sens. 1994, 15, 1611-1632. DOI: 10.1080/01431169408954195.

Geertsema, M., Highland, L., Vaugeouis, L. (2009). Environmental Impact of Landslides. Book chapter: Landslides - Disaster risk reduction, Publisher: Springer, Editors: Kyoji Sassa, Paolo Canuti. DOI: 10.1007/978-3-540-69970-5_31.

Guerschman J.P., Paruelo, J.M., Bela, C.D., Giallorenzi, M.C., Pacin, F. (2003). Land cover classification in the Argentine Pampas using multi-temporal Landsat TM data. International Journal of Remote Sensing. 24: 3381-3402. DOI: 10.1080/0143116021000021288.

Jensen, J.R. (1996). Introductory Digital Image Processing: A Remote Sensing Perspective. 2nd ed.; Prentice Hall PTR: Upper Saddle River, NJ, USA, 1996.

Joshi, P.K., Rawat, A., Narula, S., Sinha, V. (2012). Assessing impact of climate change on forest cover type shifts in Western Himalayan Eco-region. J. For. Res., 23, 75-80. DOI: 10.1007/s11676-012-0235-7. 
Sur U., Singh P.: Assessment of landscape change of Lesser Himalayan road corridor of Uttarakhand, India

Khanduri, S. (2017). Landslide Hazard around Mussoorie: The Lesser Himalayan tourist destination of Uttarakhand, India. J Geogr Nat Disaster vol7 issue2, doi: 10.4172/2067-087 1000200 .

Lambin, E.F., Turner, B.L., Geist, H.J., Agbola, S.B., Angelsen, A., Folke, C., Bruce, J.W., Coomes, O.T., Dirzo, R., George, P.S. (2001). The causes of land-use and land-cover change: Moving beyond the myths. Globak Environ. Chang. 2001, 11, 261-269.

Macchi, M., ICIMOD (2010). Mountains of the World-Ecosystem Services in a Time of Global and Climate Change. ICINOD Team, Kathmandu, Nepal. FAO. https://lib.icimod.org/record/26882.

Mas, J. F. (1999). Monitoring land-cover changes: a comparison of change detection techniques. Int. J. Remote Sens. 20, 139-152. doi: 10.1080/014311699213659.

Mas, J.F., Velazquez, A., Gallegos, J.R.D., Saucedo, R.M., Alcantare, C., Bocco, G., Castro, R., Fernandez, T., Vega, A.P. (2004). Assessing land use/cover changes: a nationwide multidate spatial database for Mexico. International Journal of Applied Earth Observation and Geoinformation, 5: 249-2. DOI: 10.1016/j.jag.2004.06.002.

Meyer, W.B. and Turner II, B.L. (1992). Human Population Growth and Global Land-Use/Cover Change. Annu. Rev. Ecol. Syst. 1992, 23, 39-61. DOI: 10.1146/annurev.es.23.110192.000351.

Ives, J.D. and Messerli, B. (1990). The Himalayan Dilemma: Reconciling Development and Conservation. Geographical Review, 81(1):124. DOI: 10.2307/215189.

Nseka, D., Mugagga, F., Bamutaze, Y., Bob, N. (2019). The Fragility of Agricultural Landscapes and Resilience of Communities to Landslide Occurrence in the Tropical Humid Environments of Kigezi Highlands in South Western Uganda. Book chapter: Agriculture and Ecosystem Resilience in Sub Saharan Africa. DOI: 10.1007/978-3-030-12974-3_13.

Pachauri, A.K. (2010). Landslide hazard mapping and assessment in Himalayas. Fifth Int Conf on Recent Advances in Geotechnical Earthquake Engineering and Soil Dynamics 22, May 24-29 2010 San Diego, California USA, Retrieved November 2, 2010, from http:scholarsmine.mst.edu/icrageesd/ 05Sicrageesd/session04b/22.

Paolini, L., Grings, F., Sobrino, J.A., Jiménez Muñoz, J.C., Karszenbaum, H. (2006). Radiometric correction effects in Landsat multi-date/multi-sensor change detection studies. Int. J. Remote Sens., 27, 685-704. DOI: 10.1080/01431160500183057.

Pandit, M.K.; Sodhi, N.S.; Koh, L.P.; Bhaskar, A., Brook, B.W. (2007). Unreported yet massive deforestation driving loss of endemic biodiversity in Indian Himalaya. Biodivers. Conserv. 16, 153-163. DOI: 10.1007/s10531-006-9038-5.

Pauleit, S., Ennos, R., Golding, Y. (2005). Modeling the environmental impacts of urban land use and land cover change - a study in Merseyside, UK. Landsc. Urban Plan. 71, 295310. DOI: 10.1016/j.landurbplan.2004.03.009.

Petit, C. C., Scudder, T., Lambin, E. F. (2001). Quantifying processes of land-cover change by remote sensing: Resettlement and rapid land-cover changes in south-eastern Zambia. Int. J. Remote Sens., 22(17):3435-3456. doi: 10.1080/01431160010006881.

Prancevic, J. P., Lamb, M. P., McArdell, B. W., Rickli, C. (2020). Decreasing landslide erosion on steeper slopes in soil-mantled landscapes. Geophysical Research Letters. doi: 10.1029/2020GL087505. 
Rai, S.C., Sharma, E., Sundriyal, R.C. (1994). Conservation in the Sikkim Himalaya: traditional knowledge and land-use of the Mamlay watershed. Environ. Conserv. 21 (1), 30 34. https://doi.org/10.1017/s0376892900024048.

Rao, K.S. and Pant, R. (2001). Land use dynamics and landscape change pattern in a typical micro watershed in the mid elevation zone of central Himalaya, India. Agriculture, Ecosystems and Environment 86 (2001) 113-123. DOI: 10.1016/S0167-8809(00)00274-7.

Reichenbach, P., Busca, C., Mondini, A. C., Rossi, M. (2014). The influence of land use change on landslide susceptibility zonation: the Briga Catchment test site (Messina, Italy). Environ. Manage., 54, 1372-1384. doi: 10.1007/s00267-014-0357-0.

Ridding, L., Newton, A. C., Redhead, J. W., Watson, S., Rowland, C. S. (2020). Modelling historical landscape changes. Landscape Ecol. (2020). doi: 10.1007/s10980-020-01059-9.

Riebsame, W.E., Meyer, W.B., Turner, B.L., 1994. Modeling land-use and cover as part of global environmental change. Clim. Change 28, 45-64. doi: 10.1007/BF01094100.

Riechers, M., Balazsi, A., Betz, L., Jiren, T. S., Fischer, J. (2020). The erosion of relational values resulting from landscape simplification. Landscape Ecol. (2020), Open Access. https://doi.org/10.1007/s10980-020-01012-w.

Sharma, S. and Roy, P.S. (2007). Forest fragmentation in the Himalaya: A Central Himalayan case study. Int. J. Sustain. Dev. World Ecol., 14, 201-210. DOI: 10.1080/13504500709469720.

Sharma, R., Xu, J., Sharma, G. (2007). Traditional agroforestry in the eastern Himalayan region: land management system supporting ecosystem services. Tropical Ecol. 48 (2), 189200.

Sharma, M., Areendran, G., Raj, K., Sharma, A., Joshi, P.K (2016). Multitemporal analysis of forest fragmentation in Hindu Kush Himalaya: A case study from Khangchendzonga Biosphere Reserve, Sikkim, India. Environ. Monit. Assess. 2016, 188.

Sharma, A., Sur, U., Singh, P., Rai, P.K., Srivastava, P.K. (2020). Probabilistic Landslide Hazard Assessment using Statistical Information Value (SIV) and GIS Techniques: A Case Study of Himachal Pradesh, India. Book Chapter in Wiley on Technique for Disaster Risk Management and Mitigation. 173-208, ISBN: 978-1-119-35918-0, May 2020.

Shastri, S., Singh, P., Verma, P., Rai, P.K., Singh, A.P. (2020). Land Cover Dynamics and their impacts on Thermal Environment of Dardi Block, Gautam Budh Nagar, India. Journal of Landscape and Ecology (2020), Vol:13, No:2, DOI: https://doi.org/10.2478 /jlecol-2020-0007.

Shrestha, U. B., Gautam, S., Bawa, K. S. (2012). Widespread Climate Change in the Himalayas and Associated Changes in Local Ecosystems. PLoS ONE 7(5):e36741. DOI: 10.1371/journal.pone.0036741.

Singh P, Thakur JK, Kumar S, Singh UC (2012). Assessment of land use/land cover using geospatial techniques in a semi-arid region of Madhya Pradesh, India. In: Thakur Singh, Prasad Gossel (eds) Geospatial techniques for managing environmental resources (pp 152 163). Springer, Heidelberg.

Singh, S.P. and Singh, J.S. (1991). Analytical conceptual plan to reforest central Himalaya for sustainable development. Environ. Manag. 1991, 15, 369-379. DOI: 10.1007/BF02393883.

Spruce, J., Bolten, J., Mohammed, I., Srinivasan, R., Lakshi, V. (2020). Mapping Land Use Land Cover Change in the Lower Mekong Basin From 1997 to 2010. Frontiers in Environmental Science 8:21. DOI: 10.3389/fenvs.2020.00021. 
Sur U., Singh P.: Assessment of landscape change of Lesser Himalayan road corridor of Uttarakhand, India

Stokes, A., Norris, J.E., van Beek, L.P.H., Bogaard, T., Cammeraat, E., Mickovski, S.B., Jennern, A., Di Iorio, A., Fourcaud, T. (2008). How vegetation reinforces soil on slopes. In book: Slope Stability and Erosion Control: Ecotechnological Solutions. DOI: 10.1007/978-1-4020-6676-4_4.

Sur, U. \& Singh, P. (2019). Landslide Susceptibility Indexing using geospatial and geostatistical techniques along Chakrata-Kalsi road corridor, India. Indian Cartographer, Journal of the Indian National Cartographic Association (INCA), 38, 2018. Publication year 2019. ISSN:0927-8392.

Tiwari, P. (2008). Land use changes in Himalaya and their impacts on environment, society and economy: A study of the Lake Region in Kumaon Himalaya, India. Adv. Atmos. Sci., 25, 1029-1042. DOI: 10.1007/s00376-008-1029-x.

Tiwari, P.C. (2000). Land-use changes in Himalaya and their impact on the plains ecosystem: Need for sustainable land use. Land Use Policy 2000, 17, 101-111. DOI: 10.1016/S0264-8377(00)00002-8.

Turner, M.G., Gardner, R.H., O’Neill, R.V. (2001). Landscape Ecology in Theory and Practice Pattern and Process. Springer-Verlag, New York.

Turner, B., Rindfuss, R. R., L. II, Entwisle, B. and Walsh, S. J. (2004). Land cover/use and population. Book chapter in Land change science: Observing, monitoring, and understanding trajectories of change on the Earth's surface, Edited by: Gutman, G.351-66. Boston: Kluwer Academic.

Twisa, S. and Buchroithner, M. F. (2019). Land-Use and Land-Cover (LULC) Change Detection in Wami River Basin, Tanzania. Land 8(9):136. DOI: 10.3390/land8090136.

Vega, A.P. (2004). Assessing land use/cover changes: a nationwide multidate spatial database for Mexico. International Journal of Applied Earth Observation and Geoinformation 5: 249-1. DOI: 10.1016/j.jag.2004.06.002.

Verma, P, Singh, P. and Srivastava, S. K. (2019). Impact of Land Use Change Dynamics of Sustainability of Groundwater Resources Using Earth Observation Data. Environment, Development and Sustainability. https://doi.org/10.1007/s10668-019-00420-6.

Voogt, J.A. and Oke, T.R. (2003). Thermal remote sensing of urban climates. Remote Sens. Environ. 86 (3), 370-384. https://doi.org/10.1016/s0034-4257(03)00079-8.

Xiao, H. and Weng, Q. (2007). The impact of land use and land cover changes on land surface temperature in a karst area of China. J. Environ. Manag. 2007, 85, 245-257. DOI: 10.1016/j.jenvman.2006.07.016.

Xu, C., Xu, X., Shen, L., Yao, Q., Tan, X., Kang, W., Ma, S., Wu, X., Cai, J., Gao, M., Li, K. (2016). Optimized volume models of earthquake-triggered landslides. Scientific Reports 6 , Article number: 29797, doi:10.1038/srep29797.

Yang, C.B., He, X.Y., Yan, F.Q., Yu, L.X., Bu, K., Yang, J.C., Chang, L.P., Zhang, S.W. (2017). Mapping the influence of land use/land cover changes on the urban heat island effect-a case study of Changchun, China. Sustainability 9, 312. DOI: 10.3390/su9020312.

Yu, H., Joshi, P.K., Das, K.K., Chauniyal, D.D., Melick, D.R., Yang, X., Xu, J. (2007). Land use/cover change and environmental vulnerability analysis in Birahi Ganga subwatershed of the Garhwal Himalaya, India. Tropical Ecol. 48 (2), 241.

Yu, H., Bian, Z., Mu, S., Yuan, J., Chen, F. (2020). Effects of Climate Change on Land Cover Change and Vegetation Dynamics in Xinjiang, China. Int. J. Environ. Res. Public Health 2020, 17, 4865; doi:10.3390/ijerph17134865 